\title{
Human Hydroxyindole- $O$-Methyltransferase: Presence of LINE-1 Fragment in a cDNA Clone and Pineal mRNA
}

\author{
SUSAN J. DONOHUE, ${ }^{1}$ PATRICK H. ROSEBOOM,${ }^{2}$ HELENA ILLNEROVA, ${ }^{3}$ JOAN L. WELLER, ${ }^{2}$ \\ and DAVID C. KLEIN ${ }^{2}$
}

\begin{abstract}
Hydroxyindole- $O$-methyltransferase (HIOMT) catalyzes the last step in the synthesis of the pineal hormone melatonin. In this study, an HIOMT clone was isolated from a human pineal cDNA library using synthetic oligonucleotide probes based on the bovine HIOMT sequence. The human sequence is unusual because it contains a $3^{\prime}$ fragment ( 84 bp) of the LINE-1 sequence, a highly repetitive sequence in the human genome and the genome of some primates and rodents. Exclusive of this LINE-1 fragment, the human HIOMT clone is $75 \%$ and $63 \%$ homologous to bovine and avian HIOMT sequences, respectively. The deduced amino acid sequence of the human cDNA clone encodes a $41.6-\mathrm{kD}$ protein. In addition, the sequence is $70 \%$ and $57 \%$ identical and $81 \%$ and $73 \%$ similar to bovine and avian HIOMT, respectively. In agreement with the results of earlier studies, it was found that vertebrate HIOMT amino acid sequences are not homologous to any other vertebrate proteins, including several methyltransferases. However, HIOMT exhibits homology with a plant $O$-methyltransferase and an internal 120-amino-acid region is approximately $35 \%$ identical to a region of four bacterial $O$-methyltransferases. The results of PCR and Southern blot analysis indicate that three species of HIOMT mRNA are typically present in the human pineal gland, only one of which contains the LINE-1 fragment. An antiserum was raised against a mixture of three synthetic peptides, corresponding to three regions of the deduced amino acid sequence of human HIOMT. This antiserum detected a single immunoreactive protein in Western blot analysis of human pineal glands. The size of the protein $(\sim 42 \mathrm{kD})$ is identical to that predicted from the HIOMT clone, including the LINE-1 fragment. The human HIOMT sequence should be useful in further studies of this enzyme and will also be of special importance in evaluating the functional significance of the inclusion of a fragment of the LINE-1 in an mRNA.
\end{abstract}

\section{INTRODUCTION}

$\mathrm{H}$ YDROXYINDOLE- $O$-METHYLTRANSFERASE ( $S$-adenosyl-Lmethionine: $N$-acetylserotonin- $O$-methyltransferase, E.C. 2.1.1.4; HIOMT) is the last enzyme in the serotonin $\rightarrow$ $N$-acetylserotonin $\rightarrow$ melatonin pathway (Axelrod and Weissbach, 1960; Sugden et al., 1986). In mammals, this enzyme is found consistently at high levels only in the pineal gland, the source of circulating melatonin (Axelrod and Weissbach, 1961; Axelrod et al., 1961). Melatonin is synthesized and secreted in a circadian pattern, and high levels invariably occur at night (Pelham et al., 1973; Lynch et al., 1975; Reppert et al., 1979). This nocturnal increase functions as a chemical indicator of night time, a signal that is of essential importance in optimally integrating seasonal changes in the length of night with seasonal changes in physiology (i.e., reproduction, mating behavior, body weight, and coat color) (Tamarkin et al., 1976; Thorpe and Herbert, 1976; Hoffmann, 1978; Kennaway et al., 1982; Bartness and Wade, 1984; Martinet and Allain, 1985). It is thought that melatonin controls circadian and seasonal physiology through actions on cells in the suprachiasmatic nucleus, the location of the master circadian oscillator (Klein et al., 1991).

'Toxicology Branch, Developmental Therapeutics Program, Division of Cancer Treatment, National Cancer Institute, Rockville, MD 20892.

${ }^{2}$ Section on Neuroendocrinology, Laboratory of Developmental Neurobiology, National Institute of Child Health and Human Development, National Institutes of Health, Bethesda, MD 20892.

${ }^{3}$ Institute of Physiology, Prague, Czechoslovakia. 
In humans, as in all mammals, the pattern of melatonin production is under photic regulation (Lewy et al., 1980; Czeisler et al., 1981; Bojkowski et al., 1987) and administration of melatonin can help reset the circadian clock (Arendt et al., 1985; Lewy et al., 1992). There is also evidence that suggests a link between melatonin and human behavior (Lewy et al., 1981; Nair et al., 1984; Beck-Friis et al., 1985; Brown et al., 1985; Sack et al., 1990), cancer (ElDomeiri and Das Gupta, 1973; Lapin and Ebels, 1976; Bartsch et al., 1991; Subramanian and Kothari, 1991), and sudden infant death syndrome (Sturner et al., 1990; Sparks and Hunsaker, 1988). Of further interest is the $>10$-fold individual-to-individual variation in the amount of melatonin produced (Arendt et al., 1977; Arendt, 1988), a variable that might reflect genetic differences in the ability to synthesize melatonin. Such differences might also be associated with a yet unidentified alteration in biological function.

In view of the critical role HIOMT plays in melatonin production and the potential role it might play in human disease, we isolated a cDNA clone encoding human HIOMT with the long-term goal of using this clone to increase our understanding of the enzyme. HIOMT has previously been cloned from avian (Voisin et al., 1992) and bovine pineal glands (Ishida et al., 1987). In the present report, a human HIOMT clone is described. In addition, results are presented indicating that three species of human HIOMT mRNA exist, probably reflecting alternative splicing. One species, represented by the clone, contains a $3^{\prime}$ fragment of the long, interspersed (LINE-1) repetitive sequence. $^{1}$

\section{MATERIALS AND METHODS}

\section{Materials}

Human pineal glands used to prepare the cDNA library were provided by the late L.J. Rubinstein (Department of Neurosurgery, University of Virginia Medical School, Charlottesville, VA). Other human pineal glands were obtained from National Disease Research Interchange (Philadelphia, PA). These pineals had a postmortem interval of 9-12 hr. Bovine tissues were obtained from Biological Research and Delivery Service (Gaithersburg, MD) and were removed within several minutes after death.

The following reagents were used: T7 DNA polymerase sequencing kit and Klenow/reverse transcriptase sequenc-

${ }^{1}$ Full-length LINE-1 sequences are $6.5 \mathrm{~kb}$ in length (Grimaldi $e t$ al., 1984; Hutchison et al., 1989) and contain active transposable elements (Hutchison et al., 1989; Singer, 1989). About $4 \times 10^{3}$ copies of the full-length LINE-1 sequences are found in the primate and rodent genomes. Even more common are $5^{\prime}$ truncated sequences ( $10^{5}$ copies per genome), which can be as short as $70 \mathrm{bp}$ (Hwu et al., 1986; Singer, 1989). Two reports have shown that the second open reading frame of the LINE-1 element is translated into a functional reverse transcriptase (Mathias et al., 1991) and this transcriptase is responsible for transcribing the LINE-1, which is then inserted into a new location in the genome (Dombroski et al., 1991). ing kit to sequence the human and bovine HIOMT clones (Promega, Madison, WI); Sequenase kit to sequence polymerase chain reaction (PCR) products (United States Biochemical, Cleveland, $\mathrm{OH}$ ); RNAsin and avian myeloblastosis virus (AMV) reverse transcriptase (Promega, Madison, WI); XL1 Blue competent cells and pBluescriptII, (Stratagene, La Jolla, CA); random primer labeling kit (Boehringer Mannheim Biochemical, Indianapolis, IN); Eco RI (New England Biolabs, Beverly, MA); AmpliTaq I (Perkin-Elmer Cetus, Norwalk, CT); Magna NT nylon membrane (Micron Separations Inc., Westboro, MA); random hexamers and deoxynucleotides (Pharmacia, Piscataway, NJ); 4\% $\rightarrow 20 \%$ gradient acrylamide gels (Novel Experimental Technology, San Diego, CA); $\left[\alpha{ }^{-32} \mathrm{P}\right] \mathrm{dCTP}$ and $\left[\alpha^{-{ }^{35}} \mathrm{~S}\right] \mathrm{dATP}$ (Amersham, Arlington Heights, IL); $\left[{ }^{14} \mathrm{C}-\right.$ methyl $]-S$-adenosyl-Lmethionine (ICN Radiochemicals, Costa Mesa, CA); [ $\left.{ }^{125} \mathrm{I}\right]-$ Protein A (New England Nuclear, Boston, MA); $N$-acetylserotonin, $S$-adenosyl-L-methionine, 5-bromo-4-chloro-3-indolyl phosphate, and nitro blue tetrazolium (Sigma, St. Louis, MO); Hybrisol I and Hybrisol II (Oncor, Gaithersburg, MD); guanidium isothiocyanate (Fluka Biochemika, Switzerland), RNazol B (Tel-Test, Inc., Friendswood, TX); SeaPlaque GTG, Nusieve GTG and SeaKem GTG (FMC BioProducts, Rockland, ME); Immobilon-P (Millipore, Bedford, MA); goat anti-rabbit IgG conjugated to alkaline phosphatase (Kirkegaard and Perry Laboratories, Inc., Gaithersburg, MD); and Protein A agarose (Life Technologies, Inc., Gaithersburg, MD).

PCR primers and 84-bp probes were synthesized using an Applied Biosystems, Inc. DNA Synthesizer 380B (Foster City, CA); a Stratalinker 1800 (Stratagene, La Jolla, CA) was used to cross-link DNA or RNA onto Magna NT and, PCR was performed using the Hybaid Thermal Reactor (National Labnet, Woodbridge, NJ) or a DNA PACER (Bellco Biotechnology, Vineland, NJ).

\section{METHODS}

Unless described below, methodological details are given in the appropriate figure legend.

\section{Isolation of human HIOMT cDNA clones}

Total RNA was isolated from human pineal glands using the method of Sargent et al. (1986) with the modification of extracting three times with $\mathrm{LiCl}_{2}$. Poly(A)RNA was purified using an oligo(dT) column. This RNA was used by Clontech (Palo Alto, CA) to prepare an amplified cDNA library in $\lambda g t 11$. The library was initially screened using clone B-18, a full-length bovine cDNA encoding for HIOMT (Ishida et al., 1987). The isolated plaques were screened further using four oligonucleotides corresponding to bases $1-24,25-75,198-248$, and 27 to -21 of the published bovine sequence (Ishida et al., 1987). Six positive plaques were isolated and the two largest inserts were subcloned (Struhl, 1985) into pBluescriptII SK ${ }^{+}$(clones 179 and 217). The nucleotide sequence of both clones was determined using the dideoxy termination method (Sanger et al., 1977). 
At a later time, the human pineal cDNA library was screened again in an effort to isolate a full-length clone that did not contain the LINE-1 fragment. The library was first screened with two synthetic 100 -mers (bases -9 to 91 and bases 1,032-1,131 from the human HIOMT sequence). Plaques that hybridized with both probes were subsequently screened using PCR. Two different primer pairs were used (5hiomt/3line +42 and scrnlib/3hiomt; see Fig. 2). The cycling parameters for the $\mathrm{PCR}$ were $94^{\circ} \mathrm{C}$ for $5 \mathrm{~min},\left(50^{\circ} \mathrm{C}\right.$ for $1 \mathrm{~min}, 72^{\circ} \mathrm{C}$ for $1.5 \mathrm{~min}, 94^{\circ} \mathrm{C}$ for $\left.45 \mathrm{sec}\right)$ 40 cycles, $50^{\circ} \mathrm{C}$ for $1.5 \mathrm{~min}, 72^{\circ} \mathrm{C}$ for $15 \mathrm{~min}$, then cool to $4^{\circ} \mathrm{C}$.

\section{Computer analysis}

The sequence of the cDNA clone and the deduced amino acid sequence were analyzed using the Sequence Analysis Software package of the Genetics Computer Group (Devereux et al., 1984). Genbank, EMBL, SwissProt, and NBRF databases were searched and homology comparisons were done using the FASTA, BESTFIT, and PILEUP programs. In addition, the deduced amino acid sequence was analyzed for probable antigenic regions using

Table 1. Immunoprecipitation of Human Pineal HIOMT ACTIVITy With ANTISERum 139A

\begin{tabular}{lccr}
\hline & \multicolumn{3}{c}{$\begin{array}{c}\text { HIOMT activity } \\
\text { Serum }\end{array}$} \\
\cline { 2 - 4 } & Dilution & Supernatant $)$ & Pellet \\
\hline Preimmune & $1: 1$ & 413 & 24 \\
Immunized & $1: 1$ & 259 & 28 \\
& $1: 3$ & 232 & 20 \\
& $1: 7$ & 222 & 13 \\
& $1: 15$ & 214 & 6 \\
\hline
\end{tabular}

Preparations of human pineal supernatant were incubated with antiserum 139A. 'Dilution' refers to the dilution of the antiserum in the reaction. Triplicate determinations were done; each value was within $10 \%$ of the given average. the PEPTIDESTRUCTURE program and secondary modification was predicted using the MOTIFS program.

\section{$P C R$}

First strand cDNA was synthesized by incubating $1 \mu \mathrm{g}$ of total RNA, $50 \mathrm{~m} M$ Tris pH $8.3,8 \mathrm{mM} \mathrm{MgCl}, 40 \mathrm{mM} \mathrm{KCl}$, $4 \mathrm{~m} M$ DTT, and $1 \mathrm{mM}$ each dATP, dGTP, dCTP, and dTTP for $2 \mathrm{~min}$ at $70^{\circ} \mathrm{C}$. The reaction was then placed on ice and 40 units of RNasin $(1 \mu \mathrm{l}), 1 \mu \mathrm{g}$ of T6 random hexamers $(1 \mu \mathrm{l})$, and 18 units of AMV reverse transcriptase (2 $\mu$ l) were added. The mixture $(50 \mu$ l final volume) was incubated for $2 \mathrm{hr}$ at $42^{\circ} \mathrm{C}$ and then stored $\left(-20^{\circ} \mathrm{C}\right)$.

The final composition of the PCR was $10 \mathrm{mM}$ Tris $\mathrm{pH}$ $8.4,3.5 \mathrm{mM}$ or $4 \mathrm{mM} \mathrm{MgCl} 2,0.01 \%$ gelatin, $50 \mathrm{mM} \mathrm{KCl}$, $5 \%$ dimethylsulfoxide (DMSO), $0.67 \mathrm{~m} M$ each dATP, $\mathrm{dCTP}, \mathrm{dTTP}$, and dGTP, 2.5 units of AmpliTaq I, $0.5 \mu M$ of each primer, and $1 \mu \mathrm{l}$ of cDNA. DMSO was added to the reactions to prevent the formation of secondary structure (Shen and Hohn, 1992). Amplification did not occur in the absence of DMSO. The reaction (final volume $50 \mu \mathrm{l}$ ) was covered with mineral oil $(50 \mu \mathrm{l})$. The cycling parameters were $94^{\circ} \mathrm{C}$ for $5 \mathrm{~min},\left(n^{\circ} \mathrm{C}\right.$ for $1 \mathrm{~min}, 72^{\circ} \mathrm{C}$ for $1 \mathrm{~min}$, $94^{\circ} \mathrm{C}$ for $\left.45 \mathrm{sec}\right) 30$ cycles, $n^{\circ} \mathrm{C}$ for $1 \mathrm{~min}, 72^{\circ} \mathrm{C}$ for 15 min, end $\left(4^{\circ} \mathrm{C}\right)$. " $n$ " refers to annealing temperature and is given in the appropriate figure legends. The sequence of PCR products was determined by using the Sequenase kit protocol for double-stranded template.

\section{Preparation of probes}

Two $\sim 450$-bp probes which flank the LINE-1 fragment were prepared by PCR amplification of the HIOMT cDNA and used for Northern blot analysis. The $5^{\prime}$ probe was synthesized using primer pair 5 hiomt/5probe and the $3^{\prime}$ probe using primers 3 probe and 3 hiomt (see Fig. 2). For Southern blot analysis, synthetic 84-bp LINE (bases 562 645) and HIOMT (bases 196-279, reverse complement) probes were used. All probes were labeled by the random primer method.

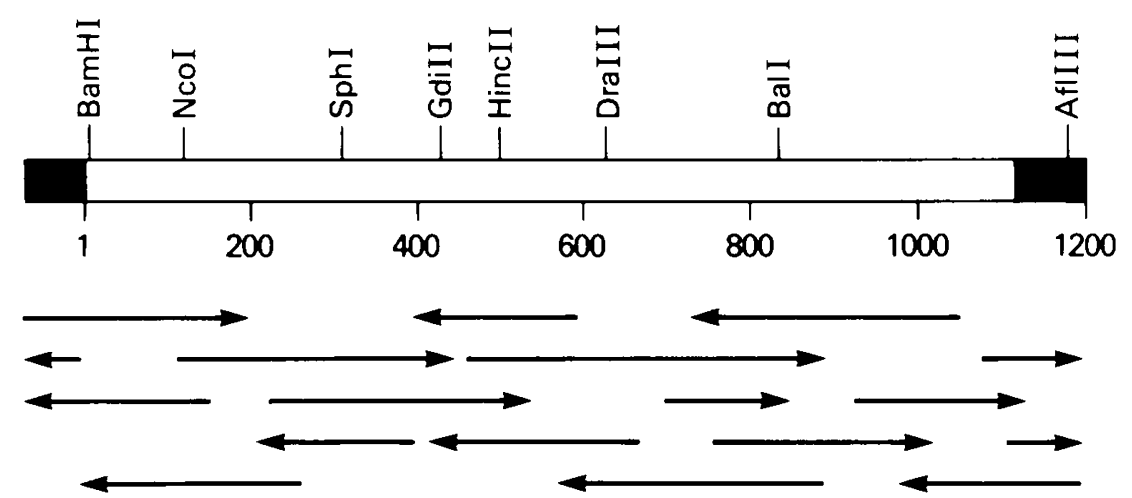

FIG. 1. Sequencing strategy. Sequence was determined for two human HIOMT cDNAs (179 and 217) subcloned into the Eco RI site of pBluescriptII SK ${ }^{+}$. The dideoxy method of sequencing was performed using either Klenow or T7 DNA polymerase and synthetic oligonucleotides as primers. Arrows identify the region and strand that was sequenced with a particular primer. The full sequence of each strand was determined at least twice. 


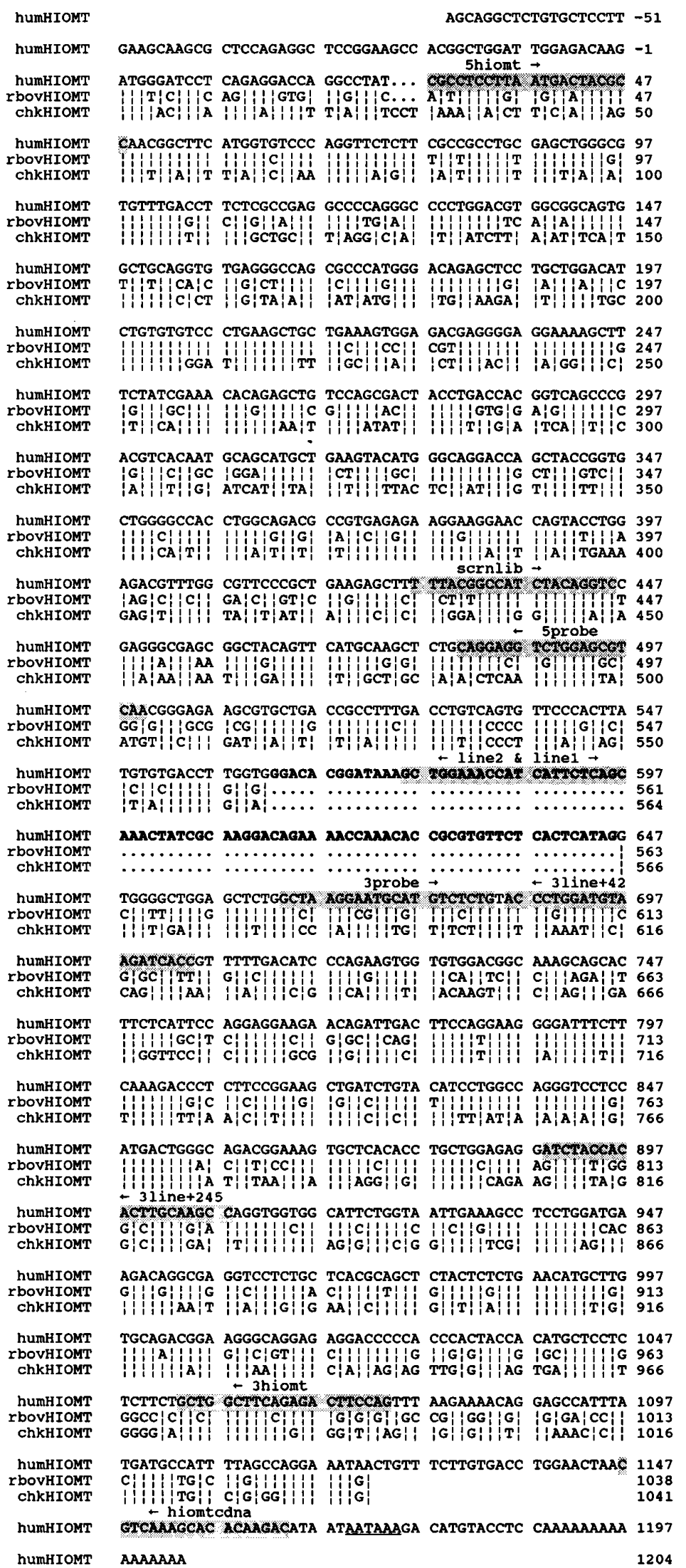




\section{RNA isolation}

Total RNA was isolated from human pineal glands using two methods, a modification of a previously described procedure (Sargent et al., 1986, without the $\mathrm{LiCl}_{2}$ step) and by extraction with RNazol B. A cow pineal gland was extracted simultaneously to provide an indication of RNA degradation during the isolation procedure. Bovine pineal RNA was never found to be degraded, as judged by the presence of strong ribosomal RNA bands and a well-defined signal following hybridization with a glyceraldehyde3-phosphate dehydrogenase (GAPDH) probe.

\section{HIOMT enzyme assay}

HIOMT activity was measured (final volume $=50 \mu \mathrm{l}$ ) using $1 \mathrm{mM} \mathrm{N}$-acetylserotonin and $0.1 \mathrm{mM}\left[{ }^{14} \mathrm{C}\right.$-methyl $]-$ $S$-adenosyl-L-methionine $(25 \mathrm{mCi} / \mathrm{mmole})$ (Sugden et al., 1986).

\section{Production, screening, and characterization of anti-human HIOMT serum}

Three peptides were synthesized (University of Notre Dame Bioscience Core Facility, Notre Dame, IN) based on regions of putative high antigenicity in human HIOMT (see Fig. 3): HH1 (L K V E T R G G K A F Y R N T E L S, residues 73-90); HH2 (A D G K C S H L L E R I Y H T C K P G G, residues 286-305); and HH3 (E G D F F K D, residues 262-268). A mixture of these peptides was used to generate antiserum 139A. A New Zealand white rabbit was injected with keyhole limpet hemocyanin conjugates of these peptides and boosted 14 days later; 6 months later the animal was boosted twice (14-day interval) with polylysine conjugates of the peptides.

To determine whether antiserum 139A could precipitate human pineal HIOMT, undiluted antiserum (2 volumes) and Protein A-agarose (1 volume) were mixed $(21 \mathrm{hr}$, $\left.4^{\circ} \mathrm{C}\right)$. Following centrifugation $\left(13,000 \times \mathrm{g}, 1 \mathrm{~min}, 4^{\circ} \mathrm{C}\right)$, the pellet was resuspended in 2 volumes of $0.05 \mathrm{M}$ sodium phosphate buffer $\mathrm{pH}$ 7.9. Human pineal glands were homogenized in 10 volumes of $0.05 M$ sodium phosphate buffer $\mathrm{pH} 7.9$, containing $0.5 \mathrm{mM}$ phenylmethylsulfonylfluoride (PMSF) and $1 \mu \mathrm{g} / \mathrm{ml}$ leupeptin. A range of volumes of the Protein A-agarose suspension were then mixed overnight with $10 \mu \mathrm{l}$ of human pineal homogenate and phosphate buffer (final volume $=100 \mu \mathrm{l}$ ). The suspension was centrifuged as before, the pellet resuspended in $100 \mu \mathrm{l}$ phosphate buffer, and both the pellet and supernatant assayed for HIOMT activity. Antiserum 139A precipitated HIOMT, albeit weakly (Table 1).

A Western blot containing protein from several human pineal glands was used to determine the specificity of the antiserum. The pooled tissues were homogenized in $20 \mathrm{mM}$ Tris, $1 \mathrm{mM}$ ethylenediamine tetraacetic acid (EDTA), 0.5 $\mathrm{m} M$ ethylene glycol-bis( $\beta$-aminoethyl ether) $N, N, N^{\prime}, N^{\prime}$ tetraacetic acid (EGTA), $0.5 \mathrm{mM}$ PMSF, and $1 \mu \mathrm{g} / \mathrm{ml}$ leupeptin and then centrifuged $(100,000 \times g, 1 \mathrm{hr})$. The soluble protein $(1.7 \mathrm{mg})$ was loaded into a $12.5-\mathrm{cm}$-wide well (12.5\% polyacrylamide gel) (Laemmli, 1970) and electrophoretically fractionated. The proteins were then transferred onto Immobilon-P (Towbin et al., 1979), and the blots were coated with $2 \%$ gelatin in Tris-buffered saline (TBS, $20 \mathrm{~m} M$ Tris $\mathrm{pH} 7.5$, and $150 \mathrm{mM} \mathrm{NaCl}$ ), dried, and cut into 3-mm-wide strips. These strips were used to determine that preimmune serum had no immunopositive reaction and that after immunization and boosting of the rabbit with the peptide mixture, the antiserum produced a strong signal at the predicted mass. For subsequent tissue distribution analysis, individual samples were applied to 5$\mathrm{mm}$-wide wells for electrophoresis, proteins were electroblotted onto Immobilin-P, and then blots were incubated $(14 \mathrm{hr})$ with antiserum 139A (1:1,000 in 1\% gelatin/TBS). After washing with TBS containing $0.05 \%$ Tween 20 (TTBS), the blots were incubated with goat anti-rabbit IgG conjugated to alkaline phosphatase $(1: 800$ in $1 \%$ gelatin/TBS) for $1.5 \mathrm{hr}$ and washed again with TTBS. Protein bands were visualized by incubating the blot with 5-bromo4-chloro-3-indolyl phosphate/nitro blue tetrazolium or by autoradiography after incubating the blot with ${ }^{125} \mathrm{I}$-labeled Protein A $(200,000 \mathrm{cpm} / \mathrm{ml})$ for $1 \mathrm{hr}$. The latter method produced less background. Antiserum 139A did not react with bovine pineal protein.

A second anti-HIOMT serum (783) was raised following methods similar to those above, except that the animal was immunized with only HH1 conjugates. Western blot analysis indicated that the resulting antiserum $(1: 1,000)$ detected a $\sim 42-k D$ protein in human pineal glands and $a \sim 39-k D$ protein in bovine pineal glands by Western blot analysis. This antiserum was not used extensively because it reacted weakly with other proteins. Antiserum 783 immunoprecipitated HIOMT activity to the same modest degree as did 139A.

Neither anti-HIOMT serum (139A or 783) produced a positive signal in immunohistochemical analyses of human pineal glands fixed by a variety of methods (H.K. Korf,

FIG. 2. Comparison of the three vertebrate HIOMT sequences. Alignment of the human HIOMT sequence (humHIOMT) with bovine (rbovHIOMT) and chicken (chkHIOMT) HIOMT sequences required insertion of a 3-bp gap in humHIOMT and rbovHIOMT at bases 28-30 (shown as "...") and an 84-bp gap (bases 563-646) in rbovHIOMT and chkHIOMT. Nucleotides identical to the humHIOMT sequence are indicated by $\mid$. The noncoding region for humHIOMT is shown as a single line and the polyadenylation signal is underlined. The LINE-1 element is shown in boldface type. PCR primers are the shaded sequences, with the primer label above the sequence and an arrow to indicate the direction of amplification. Use of each primer is described in the text. The arrows indicate the splicing site within a consensus splice sequence. For further details see Materials and Methods. 
S.J. Donohue, and D.C. Klein, unpublished results). This may indicate the reactive regions of the protein are internalized or otherwise masked, which might explain why HIOMT is not potently immunoprecipitated by these antisera.

\section{RESULTS}

\section{Sequence analysis}

The nucleotide sequence of human HIOMT cDNA clone 179 was determined (Figs. 1 and 2). The coding region is $1,122 \mathrm{bp}$ in length, the $5^{\prime}$ noncoding region is $69 \mathrm{bp}$ and the $3^{\prime}$ noncoding region is $66 \mathrm{bp}$. A second clone (217) had the same sequence.

Comparison of the human HIOMT cDNA sequence (Fig. 2) with the revised bovine (Donohue et al., 1992) and avian (Voisin et al., 1992) HIOMT sequences reveals that all three share broad regions of similarity, and that the human cDNA contains an anomalous 84-bp region. Exclusive of this region, the human HIOMT sequence is $75 \%$ and $63 \%$ homologous to the revised bovine and the avian HIOMT nucleotide sequences, respectively (Fig. 2). Further comparison of the three sequences indicates that several short regions are highly conserved.

The deduced amino acid sequence for human HIOMT (Fig. 3) is 373 residues with a predicted pI of 5.7 and size of $41.6 \mathrm{kD}$, substantially larger than the reported size (39
$\mathrm{kD}$ ) of HIOMT from other species (Nakane et al., 1983). Western blot analysis with immunodetection confirmed the mass of human HIOMT to be $\sim 42 \mathrm{kD}$, which is larger than bovine HIOMT (39 kD, Fig. 4). Avian HIOMT has an extra amino acid after residue 9 compared to mammalian HIOMT. The deduced amino acid sequences of bovine and avian HIOMT are $70 \%$ and $57 \%$ identical to human HIOMT and $81 \%$ and $73 \%$ similar to human HIOMT, respectively, excluding the anomalous region (Fig. 3). If this 84-bp region is translated into a 28 -amino-acid peptide within HIOMT, the downstream HIOMT sequence will not change

Computer analysis of the human HIOMT sequence indicates several potential sites for secondary modification (Fig. 3). Two sites are conserved among the three sequences: the casein kinase II phosphorylation site at Ser149 (150 in chicken) and the myristoylation site at Gly-216 ( 188 in bovine and 189 in chicken). In addition, 7 cysteines are conserved and it is possible that these form disulfide bonds or participate in protein thiol:disulfide exchange. The latter mechanism has been shown to alter HIOMT activity (Sugden and Klein, 1987).

A search of Genbank and EMBL databases revealed that the 84-bp anomalous region is $96 \%$ identical with a portion of the LINE-1 sequence. The presence of the LINE-1 fragment within the HIOMT CDNA clone raised the question of whether multiple species of human HIOMT mRNA exist, including one containing the LINE-1 fragment.

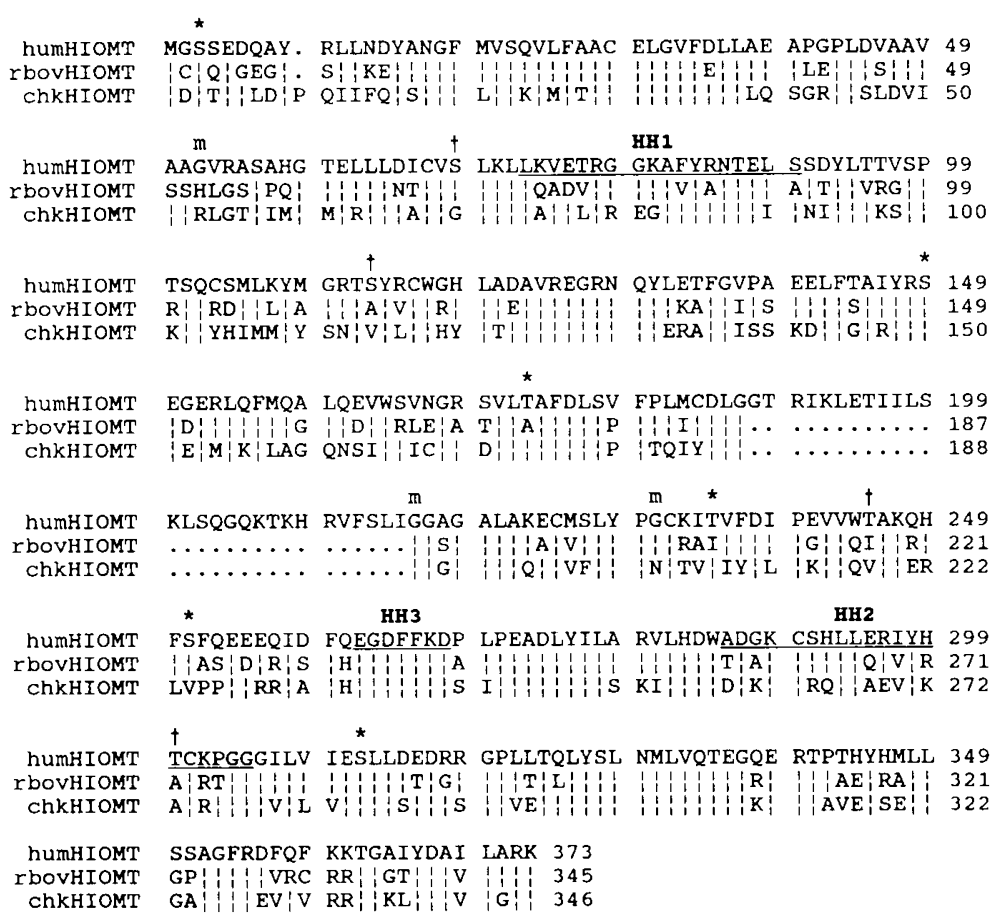

FIG. 3. Comparison of amino acid sequences. The deduced amino acid sequences for humHIOMT, bovHIOMT, and chkHIOMT are compared. In addition, the predicted secondary modifications of humHIOMT are shown. The underlined sequences correspond to the synthetic peptides $(\mathrm{HH} 1, \mathrm{HH} 2, \mathrm{HH} 3)$ used to raise antiserum in rabbits. ( $\mid$ ) Identical amino acid residues; $\left({ }^{*}\right)$ casein kinase II phosphorylation site; $(\dagger)$ protein kinase $C$ phosphorylation site; and (m) myristoylation site. For further details see Materials and Methods. 


\section{Analysis of human HIOMT mRNA: Heterogeneity and presence of LINE-1 fragment}

The presence of a LINE-1 fragment within HIOMT mRNA was initially detected by PCR using primer pairs which amplified from within the LINE-1 fragment to either an upstream (5hiomt/line2) or a downstream (line1/3hiomt) point (Fig. 2). The template used was cDNA generated from total RNA isolated from individual or pooled human pineal glands. Clone 179 served as a standard. Using the indicated primer pair (Fig. 5), products of identical size were generated from human pineal cDNA

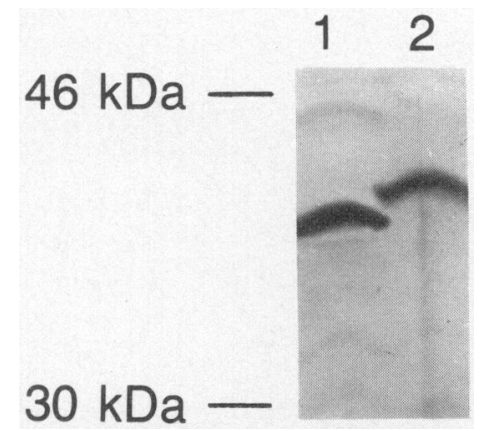

FIG. 4. Immunodetection of HIOMT in human and bovine pineal glands. Soluble protein was run on a $12.5 \%$ acrylamide gel. Preparation of the Western blot is described under Materials and Methods. Following incubation with HIOMT antiserum 783, the blot was incubated with goat anti-rabbit IgG antibody conjugated to alkaline phosphatase. Protein bands were visualized using 5-bromo4-chloro-3-indolyl phosphate/nitro blue tetrazolium. Lane 1 , bovine pineal gland; lane 2, human pineal gland.

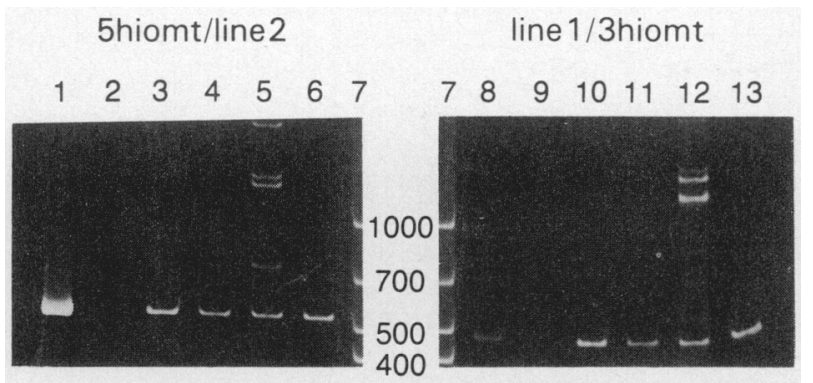

FIG. 5. PCR amplification using a LINE-1 fragment primer and an HIOMT-specific primer. PCR was performed with $4 \mathrm{mM} \mathrm{MgCl}_{2}$ and the primer pairs shown in the figure. The template for each reaction was as follows: lane 1, HIOMT cDNA clone 179; lanes 3-6, cDNA from individual human pineals; lane 7, size standards; lane 8, HIOMT cDNA clone; and lanes 10-13, cDNA from individual pineals. Lanes 2 and 9 have nothing. The annealing temperature for the reactions was $67^{\circ} \mathrm{C}$ when PCR primer pair 5hiomt/line2 was used and $63^{\circ} \mathrm{C}$ when primer pair linel/ 3hiomt was used. PCR products were run on a $4 \% \rightarrow 20 \%$ gradient acrylamide gel. For further details see Materials and Methods. and from clone 179, indicating that the LINE-1 fragment is a typical feature of only one species of human HIOMT mRNA. ${ }^{2}$

Amplification of cDNA from one gland (Fig. 5, lanes 5 and 12) generated very large products, which did not hybridize with a $5^{\prime}$ or $3^{\prime}$ HIOMT probe $(\sim 450 \mathrm{bp})$ in Southern blot analysis (data not shown). Accordingly, we believe they are artifacts.

In a second approach, Southern blot analysis of PCR products was used to verify the presence of the LINE-1 fragment in human pineal mRNA. Nearly the entire HIOMT coding region was amplified using the primer pair 5hiomt/3hiomt; the template used was cDNA synthesized from pineal total RNA. Three products were visualized on an ethidium bromide stained gel (Fig. 6). The largest product (band A) was the same size as the single band generated from the clone; this band was either very faint (Fig. 6) or undetectable (Fig. 7A, lanes 2-6) compared to the strong bands for the two smaller products (bands B and C). In other studies, we found that the relative abundance of the three PCR products appeared to be constant, regardless of the region of the HIOMT clone that was amplified. These findings suggest that the mRNA corresponding to band $\mathbf{A}$ is present in lower abundance than the other species of HIOMT mRNA.

Southern blot analysis of the PCR products revealed that a synthetic LINE probe hybridized only with band $A$. This indicates that the corresponding species of HIOMT mRNA contains the LINE-1 fragment (Fig. 7B). The very weak signal probably reflects the low amount of product present, as noted above. A synthetic 84-base 5' HIOMT probe hybridized to each of the three bands (Fig. 7C), with the same relative intensity as seen with ethidium bromide visualization. The finding that all three products hybridize with this probe indicates each band represents a different species of HIOMT mRNA. In contrast, an 84-bp scrambled LINE probe (nucleotides of LINE probe in randomized sequence) did not hybridize to the blot (not shown).

Based on these qualitative results, it appears that the LINE-1 fragment is present in both the clone and band A and that both represent the largest species of human pineal HIOMT mRNA. Bands $B$ and $C$ appear to lack the LINE-1 fragment; band $B$ is $\sim 85$ bp shorter and band $C$ is $\sim 230$ bp shorter than band $A$.

Two additional PCR experiments were performed to characterize better the smallest product (band C). The $5^{\prime}$ primer used above (5hiomt) was used with either of two $3^{\prime}$ primers (3line +245 and 3line +42 ), each of which anneals to a site between the LINE-1 fragment and the $3^{\prime}$ region to which primer 3 hiomt anneals. Three products were generated with primer pair 5hiomt/3line +245 . These were pre-

\footnotetext{
${ }^{2}$ Several observations indicate that these products are not due to contamination or nonspecific amplification. First, products were detectable only when template was added to the reaction. Second, the annealing temperatures used $\left(63^{\circ} \mathrm{C}\right.$ or $\left.67^{\circ} \mathrm{C}\right)$ permit only specific amplification to occur. Last, the same results were obtained if the cDNA used as template was synthesized using random hexamers or an HIOMT-specific oligonucleotide (primer hiomtcdna in Fig. 2, unpublished data).
} 


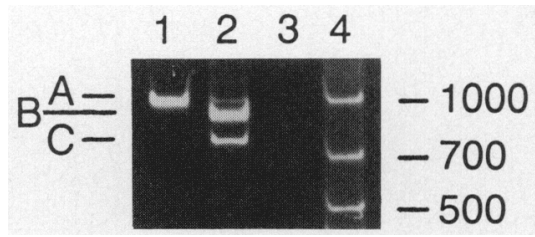

FIG. 6. PCR amplification of human pineal cDNA and the HIOMT cDNA clone. PCR was performed using the primer pair 5hiomt/3hiomt and an annealing temperature of $67^{\circ} \mathrm{C}$ and included $3.5 \mathrm{mM} \mathrm{MgCl}$. PCR products were run on a $4 \%$ to $20 \%$ gradient acrylamide gel. Lane 1, HIOMT cDNA clone; lane 2, four pooled human pineals; lane 3, water control and, lane 4, size standards. For further details see Materials and Methods.

dictably 166 bp smaller than the corresponding bands $\mathrm{A}$, $\mathrm{B}$, and C (Fig. 8). However, only two products were generated with 5 hiomt $/ 3$ line +42 . Together with the results of Southern blot analysis, this indicates that the $\sim 230$-bp region absent from the smallest mRNA species spans a major portion of the LINE-1 fragment (bp 563-646) and the region to which primer 3 line +42 anneals (bp 686-705).

The sequence of PCR products $B$ and $C$ was then determined. The results (Fig. 9) indicate that the region deleted from PCR product B corresponds exactly to the LINE-1 fragment and that $\mathrm{PCR}$ product $\mathrm{C}$ has a 225-bp deletion that includes the LINE-1 fragment and extends 141 bp further downstream,in agreement with the preceeding results. Interestingly, two splice junction sequences (Mount, 1982) exist within the HIOMT clone (Fig. 9). One is present at the $3^{\prime}$ end of the LINE-1 fragment (bp 640-647) with the splice site at the junction of the LINE-1 sequence and HIOMT sequence (between bp 646 and 647). A second recognizable splice sequence is located at bp 781-788, which corresponds to the $3^{\prime}$ end of the region deleted from PCR product $\mathrm{C}$ (splice site between pb 787 and 788).

It should be added that the human pineal cDNA library was screened again in an effort to isolate full-length cDNA inserts without the LINE-1 fragment ( $~ 85$ bp shorter). The full-length HIOMT cDNA inserts isolated were either identical in size to the clones already isolated or appeared to lack a large region $(\sim 250 \mathrm{bp}$ ) including the sequence to which primer 3 line +42 anneals. Accordingly, these smaller cDNA inserts and PCR product $C$ may represent the same species of human HIOMT mRNA.

\section{Variability in pineal HIOMT levels}

Analysis of samples of homogenates (60 $\mu \mathrm{g}$ protein/sample) of 14 individual human pineal glands indicated that all contained a $42-\mathrm{kD}$ protein that reacts with antiserum 139A (Fig. 10, see footnote 3 ). In addition, it was evident that the intensity of the HIOMT signal varied markedly between individuals.

${ }^{3}$ HIOMT was immunodetected in the homogenates of an additional 10 individual human pineal glands (S.J. Donohue, B. Kolachana, J. Kleinman, and D.C. Klein, unpublished results).

\section{A. Ethidium bromide staining}

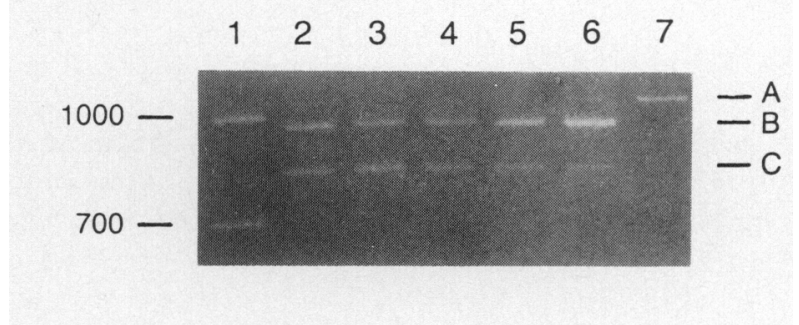

B. Southern blot: LINE probe

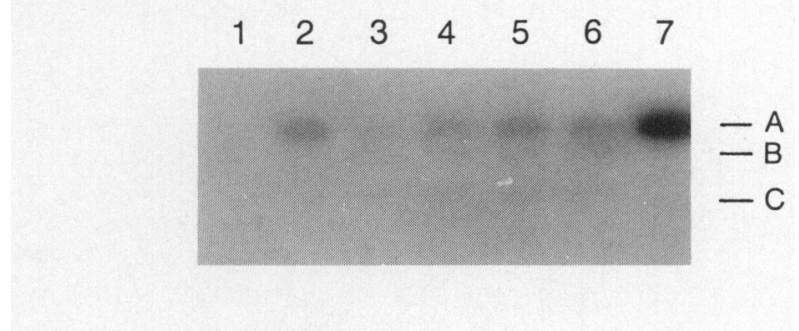

C. Southern blot: $5^{\prime}$ HIOMT probe

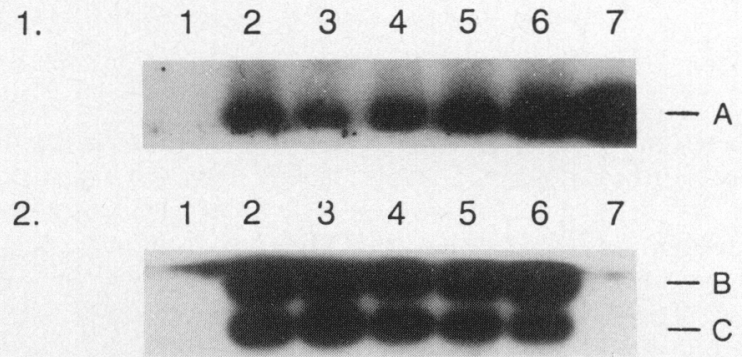

FIG. 7. Southern blot analysis of PCR products. PCR was performed using the primer pair Shiomt/3hiomt and contained $3.5 \mathrm{mM} \mathrm{MgCl} 2$. The template for each reaction was as follows: lanes 2-5, cDNA from individual human pineals; lane 6, cDNA from pooled human pineals (different pineals than lanes 2-5); lane 7, human HIOMT cDNA clone 179. Lane 1 contains size standards. The products were run on a $3 \%$ NuSieve GTG:Seakem GTG (3:1) gel made with $40 \mathrm{~m} M$ Tris-acetate and $1 \mathrm{~m} M$ EDTA. A. The PCR products are visualized by ethidium bromide staining. B. The gel was semi-dry blotted onto Magna NT and then the blot was incubated for $4 \mathrm{hr}$ at $42^{\circ} \mathrm{C}$ in Hybrisol I ( $50 \%$ formamide). The LINE probe (synthetic oligonucleotide corresponding to the LINE-1 fragment, bases 562-645) was ${ }^{32} \mathrm{P}$-labeled and added to the prehybridization solution. Following incubation for $14 \mathrm{hr}$ at $42^{\circ} \mathrm{C}$, the blot was washed twice ( $20 \mathrm{~min}$ each) at room temperature with $150 \mathrm{mM}$ sodium chloride, $15 \mathrm{mM}$ sodium citrate $(1 \times$ SSC) containing 1\% SDS and then exposed to film. C. The same blot was hybridized with a synthetic 84-base HIOMT probe (bases 279-196). The blot was stripped of the LINE probe $\left(20-30 \mathrm{~min}\right.$ in water, $\left.\leq 100^{\circ} \mathrm{C}\right)$, allowed to prehybridize as described above and then the ${ }^{32} \mathrm{P}$-labeled HIOMT probe was added. Following an overnight incubation at $42^{\circ} \mathrm{C}$, the blot was washed as described above and exposed to film. The signal from band B was so much stronger than that of band A that it was not possible to delineate signals from these bands. Consequently, the blot was cut between bands A and B and both sections were exposed to film (6 days) separately. For further details see Materials and Methods. 


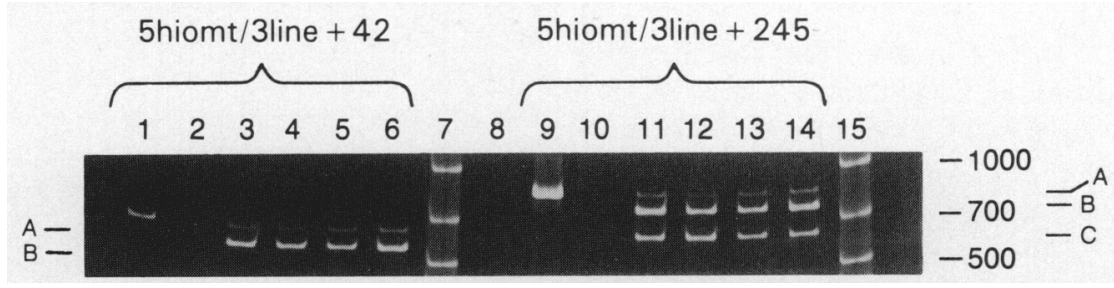

FIG. 8. PCR amplification using HIOMT-specific primer pairs. The PCR was performed with $3.5 \mathrm{mM} \mathrm{MgCl} 2$, the indicated primer pairs, and an annealing temperature of $63^{\circ} \mathrm{C}$. The template for each reaction was: lane 1, HIOMT cDNA clone 179; lanes 3-6, cDNA from individual human pineals; lane 9, HIOMT cDNA clone; lanes 11-14, cDNA from individual pineals. Lanes 7 and 15 have size standards and lanes 2, 8, and 10 are blank. PCR products were resolved on a $4 \% \rightarrow 20 \%$ gradient acrylamide gel. For further details see Materials and Methods.

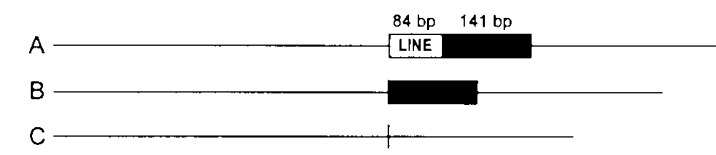

551 Gtgaccttgg tgggacacg ataAagctgg aAaccatcat tctcagcaAa

601 ctatcGcaAg gacagaAaA caAacaccGc gtgttctcac tcatagGtgG

651 GGCTGGAGCT CTGGCTAAGG AATGCATGTC TCTGTACCCT GGATGTAAGA

701 TCACCGTTTT TGACATCCCA GAAGTGGTGT GGACGGCAAA GCAGCACTTC

751 TCATTCCAGG AGGAAGAACA GATTGACTTC CAGGAAGGGG ATTTCTTCAA

FIG. 9. Illustration of regions deleted from two HIOMT PCR products. PCR amplification of human HIOMT cDNA using primers 5hiomt and 3hiomt (see Fig. 2) generated three PCR products that are represented schematically (top). Determination of the sequence of the two shorter products (B and $\mathrm{C}$ ) indicated that the LINE-1 fragment (clear box in schematic and sequence in bold type) is absent from PCR products B and C. An additional 141-bp region (shaded box in schematic and underlined sequence) is absent from product $\mathrm{C}$. Arrows indicate splicing sites.

\section{DISCUSSION}

This investigation has provided new information about human HIOMT in the following areas: sequence, mRNA heterogeneity, and individual variability. These topics will be discussed sequentially below.

\section{Sequence}

Analysis of the nucleotide sequence of the human HIOMT cDNA clone described in this report reveals that it is comprised of two distinct components. One is homologous to the HIOMT cDNA clone isolated from avian and bovine pineal glands; a second is highly homologous to a region of the LINE-1 sequence.

There are a number of short, highly conserved regions shared by the three HIOMT sequences, which we suspect contribute to substrate specificity. A longer conserved region (64\% identical between all three; residues $254-341$ ) is notable for another reason. It includes a 35 -amino-acid se- quence (residues 261-295) that is homologous among several methyltransferases (Motamedi and Hutchinson, 1987; Kaneda et al., 1988; Armstrong et al., 1989; Salminen et al., 1990; Bertocci et al., 1991; Bugos et al., 1991; Lacalle et al., 1991). This region is somewhat larger than that previously identified (residues 262-287) as exhibiting homology among methyltransferases (Voisin et al., 1992). This sequence may represent the site to which the methyl donor $S$-adenosyl-L-methionine binds (Bugos et al., 1991; Lacalle et al., 1991).

Interestingly, a large region of the methyltransferases from Rhodobacter capsulata, Streptomyces alboniger, and Streptomyces glaucescens is homologous with the HIOMT amino acid sequences (approximately 35\% identity, residues 235-354; see also Refs. Motamedi and Hutchinson, 1987; Laccalle et al., 1991). In addition, a methyltransferase isolated from aspen (lignin-bispecific $O$-methyltransferase) is homologous with HIOMT (overall $25 \%$ identity and $74 \%$ similarity to humHIOMT excluding the LINE-1 fragment) with even higher homology at the carboxyl terminus (Bugos et al., 1991). In contrast, human (Bertocci et al., 1991) and rat (Salminen et al.,m 1990) catechol-Omethyltransferase or human phenylethanolamine- $N$-methyltransferase (Kaneda et al., 1988) have extremely limited homology with HIOMT.

It should be noted that bacterial $O$-methyltransferases and HIOMT are both regulated by light, indicating that this may have been conserved as well during the course of evolution. This association may have originated within an ancestral form of the photosynthetic bacterium Rhodobacter capsulata, as discussed in detail elsewhere (Klein et al., 1992.

The 84-bp LINE-1 fragment found in the human HIOMT cDNA clone is $96 \%$ identical with the $3^{\prime}$ portion of the second long open reading frame (ORF-2) and has the same open reading frame as is found in ORF-2 (Fig. 11) (Scott et al., 1987). In addition, a region of humHIOMT (residues 188-217), comprised of the LINE-1 fragment and two amino acids extending $3^{\prime}$ into the HIOMT component, has $90 \%(27 / 30)$ identity with the carboxy-terminal residues of ORF-2. The significance of the inclusion of the carboxy-terminal region LINE-1 is not known. It should be added that the insertion of the LINE-1 fragment would still allow the correct translation of the downstream portion of HIOMT. 


\section{Heterogeneity}

The results of PCR analysis indicate that three species of HIOMT mRNA exist in the human pineal gland. The largest HIOMT mRNA contains the truncated LINE-1 sequence, whereas the two smaller species lack the LINE-1 fragment. It was not possible to verify the existence of three HIOMT mRNAs using Northern blot analysis because the RNA isolated from human pineal tissue was partially degraded, making it difficult to resolve species of mRNA of similar size (unpublished data).

The presence of three HIOMT mRNA species could reflect the presence of three copies of the HIOMT gene in the human genome. However, this does not appear to be the case since recent studies indicate that only a single copy of the gene exists (Yi et al., 1993). Consequently, it is reasonable to conclude that the three mRNA species encoding

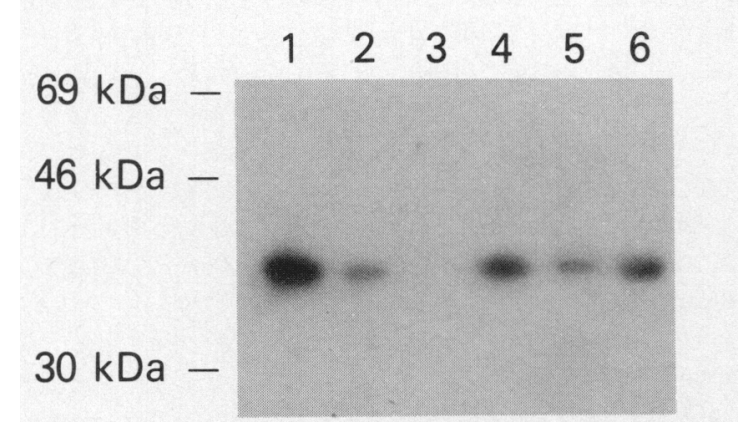

FIG. 10. Immunodetection of HIOMT from individual human pineal glands. Homogenates were prepared from individual pineal glands as described under Materials and Methods. Samples containing $60 \mu \mathrm{g}$ of protein were run on a $12.5 \%$ acrylamide gel. The HIOMT antiserum used was 139A. Protein bands were visualized by incubating the blot with ${ }^{125}$ I-labeled protein $A$ and autoradiography. The film was exposed for 10 days. Lane 1, Pineal 1; lane 2, pineal 2; lane 3, pineal 4; lane 4, pineal 5; lane 5, pineal 7; and lane 6 , pool of pineals 1-7. For further details see Materials and Methods. for HIOMT are due to alternative splicing across one or more introns. An intron:exon splice junction sequence (Mount, 1982) at the $3^{\prime}$ end of the LINE-1 fragment probably generates the mRNA species corresponding to PCR product B (Fig. 9). A recognizable splice site also occurs betweeen base pairs 787 and 788, and sequence analysis indicates that the deletion in produce $\mathrm{C}$ encompasses bases 563-787. The presence of splice junction sequences indicates that alternative splicing can occur. It should be added that a consensus splice junction sequence is not present at the $5^{\prime}$ end of the LINE-1 fragment in the clone because a single base is missing (Fig. 11); however, it appears that splicing takes place here. Resolution of this issue requires determination of the structure of the gene in this region.

Sequence analysis also reveals three features that might be linked to the mechanism of insertion of the LINE-1 fragment into the HIOMT gene. The first is the presence of a 19-bp repeat sequence on either side of the fragment (bases 535-553 and 631-649), in which 15 bp are identical (Fig. 11). This repeat sequence suggests that the LINE-1 fragment could have been inserted into the HIOMT gene by nonhomologous recombination, the mechanism through which LINE-1 sequences are generally thought to be inserted (Singer, 1989). The second is that the consensus LINE-1 sequence (Scott et al., 1987) is homologous to HIOMT in both directions beyond the $84 \mathrm{bp}$ inserted portion (Fig. 11). A 5-bp sequence immediately $3^{\prime}$ to the LINE-1 insert is $100 \%$ identical and the region immediately $5^{\prime}$ of the insert has $9 / 11$ bp identity (with 1 bp insertion). This is consistent with the possibility that the insertion occurred through homologous recombination. The third is that the full-length consensus LINE-1 sequence has splice sites that allow the excision of a fragment corresponding exactly to the LINE-1 fragment in the HIOMT cDNA clone (Fig. 11). The importance of these features in explaining how the LINE-1 fragment was inserted into the HIOMT gene will become clear when more is known about the structure of the HIOMT gene.

Although three HIOMT mRNA species exist, Western blot analysis revealed only a single immunoreactive protein

\begin{tabular}{|c|c|c|c|c|c|c|}
\hline humHIOMT & TTGACCTGTC & AGTGTTCCCA & CTTATGTGTG & ACCTTGGT G & GGACACGGAT & 572 \\
\hline Licons & ATG $\mid$ AGCCA & TAAAAAAgG! & TGAG ITCA $\mid 1$ & $A !$ & & 5810 \\
\hline $\begin{array}{l}\text { humHIOMT } \\
\text { L1Cons }\end{array}$ & 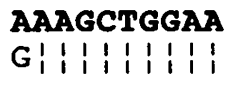 & 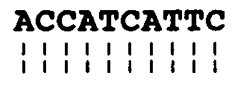 & $\begin{array}{l}\text { CAAACT } \\
111 \\
11\end{array}$ & $\begin{array}{l}\text { ATCGCAAGGA } \\
\begin{array}{llllllllll}1 & 1 & 1 & 1 & 1 & 1 & 1 & 1 & 1 & 1 \\
1 & 1 & 1 & 1 & 1 & 1 & 1 & 1 & 1\end{array}\end{array}$ & $\begin{array}{l}\text { CAGAAAACCA } \\
\begin{array}{llllllllll} & 1 & 1 & 1 & 1 & 1 & 1 & 1 & 1 & 1 \\
1 & 1 & 1 & 1 & 1 & 1 & 1 & 1 & 1\end{array}\end{array}$ & $\begin{array}{r}622 \\
5860\end{array}$ \\
\hline $\begin{array}{l}\text { humHIOMT } \\
\text { L1Cons }\end{array}$ & $\begin{array}{l}\text { AACACCGCGT } \\
\mid \text { I I } \mid \text { I } \mid \text { | }\end{array}$ & $\frac{\text { GTTCTCACTC }}{1: 1}$ & 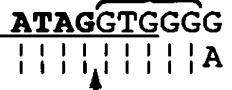 & $\begin{array}{l}\text { CTGGAGCTCT } \\
\mathrm{A} \mid \mathrm{T} ! \mathrm{A}, \mathrm{AA}\end{array}$ & $\begin{array}{r}662 \\
5900\end{array}$ & \\
\hline
\end{tabular}

FIG. 11. Comparison of the LINE-1 region of HIOMT to the homologous region of the consensus LINE-1 sequence. Identical bases in the two sequences are indicated by $\mid$. The lowercase letter at position 5,778 indicates two bases ( $\mathrm{G}$ or $\mathrm{T}$ ) occur at nearly equal frequency. The sequence in bold is the LINE-1 sequence included in the HIOMT clone. The brackets identify the regions of identity between humHIOMT and L1Cons, which extend beyond the 84-bp LINE-1 insertion. The arrows indicate the splicing site within a consensus splice sequence. The underlined regions identify the 19-bp repeat which surrounds the LINE-1 fragment. One repeat spans the $3^{\prime}$ end of LINE-1 and HIOMT; $5^{\prime}$ to the LINE-1, the repeat is entirely within the HIOMT sequence. The stop codon at the end of ORF-2 is shaded. L1Cons, Consensus sequence for LINE-1. 
band, the size of which is identical to that predicted for HIOMT containing the LINE-1 fragment. This suggests that only one species of HIOMT mRNA may be translated in the cell, or that two species are relatively unstable. If this is the only form of HIOMT present, it appears that it would represent the active form of HIOMT. Other forms of HIOMT may be present, but are undetectable with the methods used.

\section{Individual variability}

Serum melatonin levels vary dramatically between individuals (Arendt et al., 1977; Arendt, 1988). In agreement with these earlier findings, we have shown that HIOMT immunoreactivity differs markedly between individuals. The basis of this variability is unknown. It might reflect individual-to-individual differences in expression of the enzyme at the time of death or in post-mortem degradation of the enzyme.

\section{ACKNOWLEDGMENTS}

We would like to express our appreciation to: T. Deguchi (Tokyo Metropolitan Institute for Neurosciences) for the generous gift of clone B-18; I. Owens and J. Ritter (NICHD) for their assistance in our sequencing efforts; P.J. Donohue (American Red Cross) for the GAPDH probe; O.W. McBride ( $\mathrm{NCI}$ ) for discussions regarding the structure and localization of the human HIOMT gene; E. Ginns (NIMH) for support in the initial screening of the human cDNA library; and, the late L.J. Rubinstein (University of Virginia) and his staff for providing the tissues that were used to construct the human pineal cDNA library.

The nucleotide sequence reported in this paper has been submitted to the GenBank/EMBL Data Bank with accession number M83779.

\section{REFERENCES}

ARENDT, J. (1988). Melatonin and the human circadian system. In Melatonin: Clinical Perspectives. A. Miles, D.R.S. Philbrick, and C. Thompson, eds. (Oxford Medical Publications, Oxford, England) pp. 43-61.

ARENDT, J., WETTERBERG, L., HEYDEN, T., SIZONENKO, P.C., and PAUNIER, L. (1977). Radioimmunoassay of melatonin: Human serum and cerebrospinal fluid. Hormone Res. 8, 65-75.

ARENDT, J., BOJKOWSKI, C., FOLKARD, S., FRANEY, C., MARKS, V., MINORS, D., WATERHOUSE, J., WEVER, R.A., WILDGRUBER, C., and WEIGHT, J. (1985). Some effects of melatonin and the control of its secretion in humans. In Photoperiodism, Melatonin and the Pineal. D. Evered and S. Clark, eds. (Pitman, London, Ciba Foundation Symposium 117) pp. 266-279.

ARMSTRONG, G.A., ALBERTI, M., LEACH, F., and HEARST, J.E. (1989). Nucleotide sequence, organization, and nature of the protein products of the carotenoid biosynthesis gene cluster of Rhodobacter capsulatus. Mol. Gen. Genet. 216, 254-268.

AXELROD, J., and WEISSBACH, H. (1960). Enzymatic $O$ - methylation of $N$-acetylserotonin to melatonin. Science 131, 1312.

AXELROD, J., and WEISSBACH, H. (1961). Purification and properties of hydroxyindole- $O$-methyl transferase. J. Biol. Chem. 236, 211-213.

AXELROD, J., MACLEAN, P.D., ALBERS, R.W., and WEISSBACH, H. (1961). Regional distribution of methyl transferase enzymes in the nervous system and glandular tissues. In $R e$ gional Neurochemistry. S.S. Kety and J. Elkes, eds. (Pergamon Press, Oxford, England) pp. 307-311.

BARTNESS, T.J., and WADE, G.N. (1984). Photoperiodic control of body weight and energy metabolism in Syrian hamsters (Mesocricetus auratus): Role of pineal gland, melatonin, gonads, and diet. Endocrinology 114, 492-498.

BARTSCH, C., BARTSCH, H., BELLMANN, O., and LIPPERT, T.H. (1991). Depression of serum melatonin in patients with primary breast cancer is not due to an increased peripheral metabolism. Cancer 67, 1681-1684.

BECK-FRIIS, J., KJELLMAN, B.F., APERIA, B., UNDÉN, F., VON ROSEN, D., LJUNGGREN, J.-G., and WETTERBERG, L. (1985). Serum melatonin in relation to clinical variables in patients with major depressive disorder and a hypothesis of a low melatonin syndrome. Acta Psychiatr. Scand. 71, 319-330.

BERTOCCI, B., MIGGIANO, V., DA PRADA, M., DEMBIC, Z., LAHM, H.W., and MALHERBE, P. (1991). Human catechol- $O$-methyltransferase: Cloning and expression of the membrane-associated form. Proc. Natl. Acad. Sci. USA 88, 14161420 .

BOJKOWSKI, C.J., ALDHOUS, M.E., ENGLISH, J., FRANEY, C., POULTON, A.L., SKENE, D.J., and ARENDT, J. (1987). Suppression of nocturnal plasma melatonin and 6-sulphatoxymelatonin by bright and dim light in man. Horm. Metabol. Res. 19, 437-440.

BROWN, R., KOCSIS, J.H., CAROFF, S., AMSTERDAM, J., WINOKUR, A., STOKES, P.E., and FRAZER, A. (1985). Differences in nocturnal melatonin secretion between melancholic depressed patients and control subjects. Am. J. Psychiatry 142, 811-816.

BUGOS, R.C., CHIANG, V.L.C., and CAMPBELL, W.H. (1991). cDNA cloning, sequence analysis and seasonal expression of lignin-bispecific caffeic acid/5-hydroxyferulic acid $O$ methyltransferase of aspen. Plant Mol. Biol. 17, 1203-1215.

CZEISLER, C.A., RICHARDSON, G.S., ZIMMERMAN, J.C., MOORE-EDE, M.C., and WEITZMAN, E.D. (1981). Entrainment of human circadian rhythms by light-dark cycles: A reassessment. Photochem. Photobiol. 34, 239-247.

DEVEREUX, J., HAEBERLI, P., and SMITHIES, O. (1984). A comprehensive set of sequence analysis programs for VAX and convex systems. Nucleic Acids Res. 12, 387-395.

DOMBROSKI, B.A., MATHIAS, S.L., NANTHAKUMAR, E., SCOTT, A.F., and KAZAZIAN, H.H. (1991). Isolation of an active human transposable element. Science 254, 1805-1808.

DONOHUE, S.J., and KLEIN, D.C. Hydroxindole- $O$-methyltransferase is undetectable in human and bovine retina (in preparation).

DONOHUE, S.J., ROSEBOOM, P.H., and KLEIN, D.C. (1992). Bovine hydroxyindole- $O$-methyltransferase: Significant sequence revision. J. Biol. Chem. 267, 5184-5185.

EL-DOMEIRI, A.A.H., and DAS GUPTA, T.K. (1973). Reversal by melatonin of the effect of pinealectomy on tumor growth. Cancer Res. 33, 2830-3822.

GRIMALDI, G., SKOWRONSKI, J., and SINGER, M.F. (1984). Defining the beginning and end of Kpn-I family segments. EMBO J. 3, 1753-1759.

HOFFMANN, K. (1978). Effects of short photoperiods on 
puberty, growth and moult in the Djungarian hamster. J. Reprod. Fert. 54, 29-35.

HUTCHISON, C.A. III, HARDIES, S.C., LOEB, D.D., SHEHEE, W.R., and EDGELL, M.H. (1989). LINEs and related retroposons: Long interspersed repeated sequences in the eucaryotic genome. In Mobile DNA. D. Berg and M. Howe, eds. (American Soc. of Microbiology, Washington, D.C.) pp. 593617.

HWU, H.R., ROBERTS, J.W., DAVIDSON, EH., and BRITTEN, R.J. (1986). Insertion and/or deletion of many repeated DNA sequences in human and higher ape evolution. Proc. Natl. Acad. Sci. USA 83, 3875-3879.

ISHIDA, I., OBINATA, M., and DEGUCHI, T. (1987). Molecular cloning and nucleotide sequence of cDNA encoding hydroxyindole- $O$-methyltransferase of bovine pineal glands. J. Biol. Chem. 262, 2895-2899.

KANEDA, N., ICHINOSE, H., KOBAYASHI, K., OKA, K., KISHI, F., NAKAZAWA, A., KUROSAWA, Y., FUJITA, K., and NAGATSU, T. (1988). Molecular cloning of cDNA and chromosomal assignment of the gene for human phenylethanolamine $\mathrm{N}$-methyltransferase, the enzyme for epinephrine biosynthesis. J. Biol. Chem. 263, 7672-7677.

KENNAWAY, D.J., GILMORE, T.A., and SEAMARK, R.F. (1982). Effect of melatonin feeding on serum prolactin and gonadotropin levels and the onset of seasonal estrous cyclicity in sheep. Endocrinology 110, 1766-1772.

KLEIN, D.C., MOORE, R.Y., and REPPERT, S.M., eds. (1991). The Suprachiasmatic Nucleus: The Mind's Clock. (Oxford University Press, New York).

KLEIN, D.C., ROSEBOOM, P.H., DONOHUE, S.J., and MARRS, B.L. (1992). Evolution of melatonin as a night signal: Contribution from a primitive photosynthetic organism. Mol. Cell. Neurosci. 3, 181-183.

LACALLE, R.A., RUIZ, D., and JIMÉNEZ, A. (1991). Molecular analysis of the $d m p M$ gene encoding an $O$-demethylpuromycin $O$-methyltransferase from Streptomyces alboniger. Gene $109,55-61$.

LAEMMLI, U.K. (1970). Cleavage of structural proteins during the assembly of the head of bacteriophage T-4. Nature 227, 680-685.

LAPIN, V., and EBELS. I. (1976). Effects of some low molecular weight sheep pineal fractions and melatonin on different tumors in rats and mice. Oncology 33, 110-113.

LEWY, A.J., WEHR, T.A., GOODWIN, F.K., NEWSOME, D.A., and MARKEY, S.P. (1980). Light suppresses melatonin secretion in humans. Science 210, 1267-1269.

LEWY, A.J., WEHR, T.A., GOODWIN, F.K., NEWSOME, D.A., and ROSENTHAL, N.E. (1981). Manic-depressive patients may be supersensitive to light. Lancet i, 383-384.

LEWY, A.J., AHMED, S., JACKSON, J.M.L., and SACK, R.L. (1992). Melatonin shifts human circadian rhythms according to a phase-response curve. Chronobiol. Int. 9, 380-392.

LYNCH, H.J., WURTMAN, R.J., MOSKOWITZ, M.A., ARCHER, M.C., and HO, M.H. (1975). Daily rhythm in human urinary melatonin. Science 187, 169-171.

MARTINET, L., and ALLAIN, D. (1985). Role of the pineal gland in the photoperiodic control of reproductive and non-reproductive functions in mink (Mustela vison). In Photoperiodism, Melatonin and the Pineal. D. Evered and S. Clark, eds. (Ciba Foundation Symnposium 117, Pitman Publishing Ltd, London) pp. 170-185.

MATHIAS, S.L., SCOTT, A.F., KAZAZIAN, H.H., BOEKE, J.D., and GABRIEL, A. (1991). Reverse transcriptase encoded by a human transposable element. Science 254, 1808-1810.

MOTAMEDI, H., and HUTCHINSON, C.R. (1987). Cloning and heterologous expression of a gene cluster for the biosynthe- sis of tetracenomycin $C$ the anthracycline antitumor antibiotic of streptomyces-glaucescens. Proc. Natl. Acad. Sci. USA 84, 4445-4449.

MOUNT, S.M. (1982). A catalogue of splice junction sequences. Nucleic Acids Res. 10, 459-472.

NAIR, N.P.V., HARIHARASUBRAMANIAN, N., and PILAPIL C. (1984). Circadian rhythm of plasma melatonin in endogenous depression. Prog. Neuro-Psychopharmacol. Biol. Psychiat. 8, 715-718.

NAKANE, M., YOKOYAMA, E., and DEGUCHI, T. (1983). Species heterogeneity of pineal hydroxyindole- $O$-methyltransferase. J. Neurochem,. 40, 790-796.

OWEN, F., FERRIER, I.N., POULTER, M., and CROW, T.J. (1983). Hydroxy-indole- $O$-methyltransferase activity in human pineals: A comparison of controls and schizophrenics. Clin. Endocrinol. 19, 313-317.

PELHAM, R.W., VAUGHAN, G.M., SANDOCK, K.L., and VAUGHAN, M.K. (1973). Twenty-four-hour cycle of a melatonin-like substance in the plasma of human males. J. Clin. Endocrinol. Metab. 37, 341-344.

REPPERT, S.M., PERLOW, M.J., TAMARKIN, L., and KLEIN, D.C. (1979). A diurnal melatonin rhythm in primate cerebrospinal fluid. Endocrinology 104, 295-301.

SACK, R.L., LEWY, A.J., WHITE, D.M., SINGER, C.M., FIREMAN, M.J., and VANDIVER, R. (1990). Morning vs evening light treatment for winter depression. Arch., Gen. Psychiatry 47, 343-351.

SALMINEN, M., LUNDSTRÖM, K., TILGMANN, C., SAVOLAINEN, R., KALKKINEN, N., and ULMANEN, I. (1990). Molecular cloning and characterization of rat liver catechol- $O$ methyltransferase. Gene 93, 241-247.

SANGER, F., NICKLEN, S., and COULSON, A.R. (1977). DNA sequencing with chain terminating inhibitors. Proc. Natl. Acad. Sci. USA 74, 5463-5467.

SARGENT, T.D., JAMRICH, M., and DAWID, I.B. (1986). Cell interactions and the control of gene activity during early development of Xenopus laevis. Dev. Biol. 114, 238-246.

SCOTT, A.F., SCHMECKPEPER, B.J., ABDELRAZIK, M., COMEY, C.T., O'HARA, B., ROSSITER, J.P., COOLEY, T., HEATH, P., SMITH, K.D., and MARGOLET, L. (1987). Origin of the human L1 elements: Proposed progenitor genes deduced from a consensus DNA sequence. Genomics 1, 113125.

SHEN, W.-H., and HOHN, B. (1992). DMSO improves PCR amplification of DNA with complex secondary structures. Trends Genet. 8, 227.

SINGER, M.F. (1989). LINE-1 sequences: Human transposable elements. In Evolutionary Tinkering in Gene Expression. M. Grunberg-Manago, B.F.C. Clark, and H.G. Zachau, eds. (NATO ASI Series, Series A: Life Sci, Plenum Press, New York, NY) vol. 159, pp. 155-162.

SPARKS, D.L., and HUNSAKER, J.C. III (1988). The pineal gland in sudden infant death syndrome: Preliminary observations. J. Pineal Res. 5, 111-118.

STRUHL, K. (1985). A rapid method for creating recombinant DNA molecules. BioTechniques 3, 452-453.

STURNER, W.Q., LYNCH, H.J., DENG, M.H., GLEASON, R.E., and WURTMAN, R.J. (1990). Melatonin concentrations in the sudden infant death syndrome. Forensic Sci. Intl. 45, 171-180.

SUBRAMANIAN, A., and KOTHARI, L. (1991). Melatonin, a suppressor of spontaneous murine mammary tumors. J. Pineal Res. 10, 136-140.

SUGDEN, D., and KLEIN, D.C. (1987). Inactivation of rat pineal hydroxyindole- $O$-methyltransferase by disulfide-containing compounds. J. Biol. Chem. 262, 6489-6493. 
SUGDEN, D., CEÑA, V., and KLEIN, D.C. (1986). Hydroxyindole- $O$-methyltransferase. Methods. Enzymol. 142, 590-596.

TAMARKIN, L., WESTROM, W.K., HAMILL, A.I., and GOLDMAN, B.D. (1976). Effect of melatonin on the reproductive systems of male and female Syrian hamsters: A diurnal rhythm in sensitivity to melatonin. Endocrinology 99, 1534-1541.

THORPE, P.A., and HERBERT, J. (1976). Studies on the duration of the breeding season and photorefractoriness in female ferrets pinealectomized or treated with melatonin. J. Endocrinol. 70, 255-262.

TOWBIN, H., GORDON, J., STAEHELIN, T., and GORDON, J. (1979). Electrophoretic transfer of proteins from polyacrylamide gels to nitrocellulose sheets: Procedure and some applications. Proc. Natl. Acad. Sci. USA 76, 4350-4354.

VOISIN, P., GUERLOTTÉ, J., BERNARD, M., COLLIN, J.-P., and COGNÉ, M. (1992). Molecular cloning and nucleo- tide sequence of a cDNA encoding hydroxyindole- $O$-methyltransferase from chicken pineal gland. Biochem. J. 282, 571576.

YI, H., DONOHUE, S.J., KLEIN, D.C., and McBRIDE, O.W. (1993). Localization of the hydroxyindole- $O$-methyltransferase gene to the pseudoautosomal region: Implications for mapping of psychiatric disorders. Hum. Mol. Genet. 2, 127-131.

Address reprint requests to: Dr. David C. Klein

Building 99, Room 6 A80 National Institutes of Health Bethesda, MD 20892

Received for publication January 18, 1993, and in revised form March 11, 1993. 